\begin{tabular}{|c|c|c|}
\hline $\begin{array}{l}\text { JURNALPENELITIAN KEBIDANAN } \\
\& \text { KESPRO }\end{array}$ & VOL. 1 NO. 2 & $\begin{array}{l}\text { EDITION: NOVEMBER } 2018- \\
\text { APRIL } 2019\end{array}$ \\
\hline & http://ejournal.delihusada.ac.id/index.php/JPK2R & \\
\hline RECEIVED: 20 JANUARI 2019 & REVISED: 20 MARET 2019 & ACCEPTED: 21 APRIL 2019 \\
\hline
\end{tabular}

\title{
PENGARUH PEMBERIAN REBUSAN DAUN SIRIH MERAH TERHADAP KEPUTIHAN PATOLOGIS PADA REMAJA PUTRI
}

\author{
Sri Wulan \\ Institut Kesehatan Medistra Lubuk Pakam, Jl. Sudirman No 38 LubukPakam \\ e-mail : wulan194@gmail.com
}

\begin{abstract}
Pathological leucorrhoea is a vaginal discharge that occurs due to a bacterial infection, a fungus in which the fluid that comes out a lot and continuously from the vagina and the color of the liquid is not clear or white or yellow or greenish. This study aims to determine the effect of giving red betel leaf decoction to pathological vaginal discharge in young women in Merbau 1 High School. This study used a quasy experimental design, purposive sampling technique, and a sample of 46 people in which 23 were in the intervention group and 23 were in the control group. The sheet pre test and post test is an instrument in this study which contains signs and symptoms of vaginal discharge. The increase in the incidence of leucorrhoea from 2 female students who experienced mild vaginal discharge to moderate vaginal discharge in the control group showed that red betel leaf decoction water was able to overcome pathological vaginal discharge compared to normal water. Based on the results of the Wilcoxon test means that there is an effect of giving red betel leaf stew to pathological vaginal discharge in young women in Merbau 1 High School. Researchers suggested that health workers, especially nurses, be able to introduce more about the benefits of red betel leaf decoction to the community, especially women, so that people were more confident in using non-pharmacological treatments.
\end{abstract}

Keywords: Leucorrhoea, red betel leaf decoction

\section{PENDAHULUAN}

Keputihan terbagi dalam dua bagian yaitu keputihan normal dan keputihan abnormal atau patologis. Keputihan yang fisiologis tidak memerlukan pengobatan, biasanya encer, bening, tidak gatal, dan tidak berbau, kadangkadang bertambah banyak, kadang-kadang berkurang, dan tidak terus-menerus. Keputihan yang abnormal mempunyai ciri-ciri yaitu cairan berwarna susu atau kehijauan, kuning atau bercampur darah, bau, sangat gatal dan disertai nyeri perut bagian bawah. Jika keputihan patologis atau abnormal dibiarkan maka dapat menyebar hingga kebagian rongga rahim dan saluran indung telur yang akhirnya dapat menyebabkan radang pada bagian panggul dan dapat menyebabkan kemandulan serta penyebab awal kanker rahim, yang bisa berujung pada kematian (Solikhah dkk, 2010).
Penyebab utama keputihan karena adanya infeksi pada vagina oleh bakteri Trichomonas Vaginalis dan Candida Albicans. Di Indonesia sekitar $75 \%$ wanita mengalami keputihan patologis (abnormal) minimal satu kali dalam hidupnya dan Lebih dari $70 \%$ wanita Indonesia mengalami keputihan yang disebakan karena jamur Candida Albicans. Angka ini berbeda dengan daerah Eropa yang hanya $25 \%$ wanita yang mengami keputihan patologis.

Febiliawanti (2009) dalam Kurniawati (2013) menyatakan bahwa dari hasil penelitiannya yang dilakukan di SMU Negeri 2 di Kebumen diperoleh dari 420 siswi terdapat 259 (62,9\%) yang mengalami keputihan. 78 siswi $(30,1 \%)$ mengatakan merasa gatal pada alat kelaminnya sehingga mereka merasa khawatir dengan kondisinya. 25 siswi $(7,7 \%)$ lainnya mengeluh keluar cairan berwarna kuning kehijauan seperti dahak dan ada juga yang mengeluh keluar cairan berwarna bening dan 


\begin{tabular}{c|c|c}
\hline $\begin{array}{c}\text { JURNALPENELITIAN KEBIDANAN } \\
\text { \& KESPRO }\end{array}$ & VOL. 1 NO. 2 & $\begin{array}{c}\text { EDITION: NOVEMBER 2018 } \\
\text { APRIL 2019 }\end{array}$ \\
\hline & http://ejournal.delihusada.ac.id/index.php/JPK2R & \\
\cline { 2 - 2 } RECEIVED: 20 JANUARI 2019 & ACCEPTED: 21 APRIL 2019 \\
\hline
\end{tabular}

encer pada waktu tertentu saja (Solikhah dkk, 2010).

Daun sirih merah (Piper crocatum Ruiv \& Pav) merupakan tanaman yang termasuk dalam famili Piperaceaeyang memiliki warna merah keperakan. Daun sirih merah mengandung senyawa fitokimia yaitu minyak atsiri, alkaloid, saponin, tanin, dan flavonoid. Masyarakat Indonesia banyak menggunakan daun sirih merah sebagai tanaman obat-obatan karena daun sirih merah dapat menghambat bakteri patogen (Nisa dkk, 2014).

Masyarakat di Indonesia juga banyak menggunakan daun sirih merah sebagai antiseptik untuk mengatasi diabetes, kanker, hipertensi, dan penyakit lainnya yang dibuat dalam bentuk teh herbal ataupun jamu tradisional, sirih merah juga dapat digunakan sebagai obat asam urat, kencing manis, dan gastritis(Martin, 2010). Air rebusan daun sirih merah dapat digunakan sebagai antiseptik yang bersifat desinfektan sebagi anti jamur, sehingga dapat menjaga kesehatan dan menyembuhkan penyakit keputihan pada organ wanita (Werdhany dkk, 2008).

Berdasarkan uraian latar belakang di atas, maka perumusan dalam penelitian ini adalah apakah ada pengaruh pemberian rebusan daun sirih merah terhadap keputihan patologis pada remaja Putri di SMA Negeri 1 Merbau?

\section{METODE}

Penelitian ini merupakan penelitian kuantitatif menggunakan desain quasy eksperiment dengan jenis rancangan Non Equivalent Control Group yang melibatkan dua kelompok yaitu kelompok intervensi dan kontrol.

Penelitian ini dilaksanakan di SMA Negeri 1 Merbau Kabupaten Labuhan Batu Utara. Penelitian ini dimulai dari bulan November 2018 - Desember 2018.P opulasi dalam penelitian ini adalah semua remaja putri di SMA Negeri 1 Merbau yaitu sebanyak 153 orang. Teknik pengambilan sampel penelitian ini adalah purposive sampling yaitu 46 orang responden (23 kelompok eksperimen dan 23 kelompok kontrol).

Metode pengumpulan data dengan menggunkan lembar observasi pre test dan post test serta metode wawancara. Analisa data yang digunakan jika data berdistribusi normal mengunakan Uji Independent T Test, apabila data tidak berdistribusi normal maka menggunakan $\mathrm{Uji} U$ Man Whitney yang dihitung dengan menggunakan SPSS dengan Taraf signifikan $95 \%(a=0,05)$.

\section{HASIL DAN PEMBAHASAN}

\section{Hasil Pre test dan Post test pada kelompok Intervensi}

Tabel 1. Perbedaan keputihan pre dan post pada kelompok intervensi

\begin{tabular}{cccccc}
\hline Variabel & $\begin{array}{c}\text { Positive } \\
\text { Ranks }\end{array}$ & $\begin{array}{c}\text { Negative } \\
\text { Ranks }\end{array}$ & $\mathbf{T}$ & $\mathbf{Z}$ & $\begin{array}{c}\mathbf{p} \\
\text { value }\end{array}$ \\
\hline $\begin{array}{c}\text { Keputihan } \\
\text { pre dan } \\
\text { post }\end{array}$ & 0.00 & 12.00 & 0.00 & - & 0.000 \\
\hline
\end{tabular}

Tabel 1 menunjukan bahwa bahwa nilai $\mathrm{p}<\mathrm{a}$ $(0.000<0.05)$ dan skor $Z$ sebesar -4.211 yang berarti ada perbedaan yang bermakna pada kelompok intervensi sebelum dan sesudah dilakukan intervensi.

Hal ini sejalan dengan hasil penelitian Firmanila dkk (2014) bahwa dari 30 sampel yang diambil secara cluster sampling, 15 sampel sebagai kelompok eksperimen dan 15 sampel sebagai kelompok kontrol. Hasil penelitian menunjukan ada penurunkan keputihan pada kedua kelompok dengan nilai $p=0.001$ ( $<a$ 0.05). Dari hasil penelitian ini diharapkan wanita yang mengalami keputihan dapat mengaplikasikan air rebusan daun sirih merah sebagai obat non farmakologis dan menjadikan daun sirih merah sebagai jenis tanaman obat di masyarkat.

Keputihan dapat teratasi jika personal higiene tetap dilakukan misalnya denga menggunakan pakaian dalam yang terbuat dari bahan katun atau pun pakaian dalam yang menyerap keringat, menjaga pola makan, istirahat yang cukup, olahraga yang rutin serta menghindari 


\begin{tabular}{c|c|c}
\hline $\begin{array}{c}\text { JURNALPENELITIAN KEBIDANAN } \\
\text { \& KESPRO }\end{array}$ & VOL. 1 NO. 2 & $\begin{array}{c}\text { EDITION: NOVEMBER 2018 - } \\
\text { APRIL 2019 }\end{array}$ \\
\hline & http://ejournal.delihusada.ac.id/index.php/JPK2R & \\
\cline { 2 - 2 } RECEIVED: 20 JANUARI 2019 & ACCEPTED: 21 APRIL 2019 \\
\hline
\end{tabular}

rasa stress. Selain itu, keputihan juga dapat diatasi melalui obat-obat farmakologis seperti obat golongan flukonazol dan obat golongan metronidazol (Endang, 2003 dalam Namira, 2012).Tetapi tidak hanya pengobatan secara farmakologis saja yang dapat digunakan, pengobatan secara non-farmakologis juga dapat digunakan salah satunya yaitu dengan menggunakan daun sirih merah yang sudah terbukti dapat menyembuhkan atau mengurangi keputihan.

\section{Hasil Pre test dan Post test pada kelompok kontrol}

Tabel 2. Perbedaan keputihan pre dan post pada kelompok kontrol

\begin{tabular}{ccccc}
\hline Variabel & $\begin{array}{c}\text { Positif } \\
\text { Ranks }\end{array}$ & $\begin{array}{c}\text { Negatif } \\
\text { Ranks }\end{array}$ & $\mathbf{Z}$ & $\begin{array}{c}\mathbf{p} \\
\text { value }\end{array}$ \\
\hline $\begin{array}{c}\text { Keputihan } \\
\text { pre dan } \\
\text { post }\end{array}$ & 2.00 & 0.00 & -1.604 & 0.109 \\
\hline
\end{tabular}

Tabel 2 menunjukkan bahwa nilai $\mathrm{p}>0.05$ $(0.109>0.05)$ dan skor Z sebesar -1.604 yang berarti bahwa tidak ada perbedaan yang signifikan pada kelompok kontrol.

Hal ini sesuai dengan hasil penelitian Kustanti (2016), yang menunjukan bahwa hasil pre test pada kelompok kontrol adalah: 21,69 $\pm 7,11$ dan post test pada kelompok kontrol adalah: $23,10 \pm 7,27$, yang artinya tidak terjadi perubahan bahkan terjadi peningkatan keputihan pada kelompok tersebut. Keputihan merupakan penyakit yang menyerang organ reproduksi wanita jika keputihan tidak segera di obati maka akan berdampak negative terhadap wanita seperti penyakit infeksi radang panggul, kanker Rahim atau kanker servik sehingga dapat menyebabkan kematian.

\section{Perbedaan keputihan antara kelompok intervensi dengan kelompok kontrol}

Untuk membandingkan data sesudah pemberian daun sirih merah pada kelompok intervensi dengan kelompok kontrol, peneliti menggunakan uji mann-whitney (nonparametric test) karena hasil uji normalitas dengan menggunakan Shapiro wilk pada kelompok intervensi adalah $0.000(p<0.05)$ sedangkan pada kelompok kontrol yaitu 0.000 $(p<0.05)$ sehingga data tidak terdistribusi normal, dimana syarat data normal jika $\mathrm{p}>\mathrm{a}$ ( $p>0.05)$.

Tabel 3 Perbedaan keputihan pada kelompok intervensi dan kelompok kontrol

\begin{tabular}{lcccc}
\hline Variabel & $\begin{array}{c}\text { Interve } \\
\text { nsi }\end{array}$ & Kontrol & $\mathbf{Z}$ & $\begin{array}{c}\mathbf{p} \\
\text { value }\end{array}$ \\
\hline $\begin{array}{l}\text { Intervensi } \\
\text { Kontrol }\end{array}$ & 12.00 & 35.00 & -5.957 & 0.00 \\
\hline
\end{tabular}

Table 3 menunjukkan bahwa nilai p $0.000<$ $0.05(\mathrm{p}<\mathrm{a})$ dan skor $Z$ sebesar -5.957 yang berarti bahwa terdapat perbedaan yang signifikan atau bermakna antara keputihan pada kelompok intervensi dan kelompok kontrol.

Hal ini sama dengan hasil penelitian Utami (2014), dimana data diperoleh diolah secara statistik dengan menggunakan uji paried $t$ test. Berdasarkan hasil analisa diperoleh bahwa usia terbanyak $(51,4 \%) 20$ 30 tahun dan pendidikan terbanyak $(51,4 \%)$ SMP, sedangkan keputihan sebelum diberikan rebusan daun sirih memiliki keputihan patologis $(74,3 \%)$ dan setelah diberikan rebusan daun sirih memiliki keputihan fisiologis (82,9\%). Hasil uji paired $t$ test didapatkan $\mathrm{p}$ value $0,000(<0.05)$ disimpulkan Rebusan daun sirih efektif terhadap penurunan keputihan ( $p$ value $<0,05$ ).

Keputihan patologis atau keputihan abnormal dapat disebabkan oleh banyak faktor, salah satu faktornya adalah karena kurangnya kebersihan organ kewanitaan, kondisi psikologis yang mengalami stress berlebihan serta menggunakan pembersih untuk membersihkan bagian organ wanita secara berlebihan.

Apabila keputihan tidak segera ditangani maka bisa menyebabkan penyakit seperti radang panggul dan dapat menyebabkan kemandulan, serta dapat menyebabkan kehamilan di luar rahim, karena kerusakan dan tersumbatnya saluran telur. Selain itu juga dapat menyebabkan infeksi di kulit ketuban, Ketuban Pecah Dini (KPD) ,persalinan prematur, dan 


\begin{tabular}{c|c|c}
\hline $\begin{array}{c}\text { JURNALPENELITIAN KEBIDANAN } \\
\text { \& KESPRO }\end{array}$ & VOL. 1 NO. 2 & $\begin{array}{c}\text { EDITION: NOVEMBER 2018 } \\
\text { APRIL 2019 }\end{array}$ \\
\hline & http://ejournal.delihusada.ac.id/index.php/JPK2R & \\
\cline { 2 - 2 } RECEIVED: 20 JANUARI 2019 & ACCEPTED: 21 APRIL 2019 \\
\hline
\end{tabular}

kelahiran bayi dengan berat lahir rendah (BBLR) (Djuanda, 2005 dalam Namira, 2012).

Penanganan keputihan patologis (abnormal) merupakan bagian dari preventif dan kuratif yang bertujuan untuk menyembuhkan wanita dari keputihan untuk selamanya serta mencegah infeksi yang berulang. Daun sirih merah merupakan satu jenis tanaman semak dan perdu. Jenis tanaman ini dapat dijumpai di kebun dan juga di halaman rumah. Daun sirih merah mempunyai kandungan senyawa fitokimia yaitu alkoloid, saponin, tanin, dan flavonoid dimana kandungan kimia tersebut dapat digunakan sebagai antimikroba (Ebadi, 2012 dalam Candrasari, 2012).

Senyawa kimia yang terdapat di daun sirih merah diketahui berpotensi sebagai antioksidan, antikanker, dan antidiabetes sedangkan kandungan tannin daun sirih merah terbukti dapat digunakan untuk mengobati keputihan baik keputihan patologis atupun fisiologis (Martin, 2010).

\section{KESIMPULAN}

Berdasarkan hasil uji untuk membandingkan keputihan pada kelompok intervensi dan kelompok kontrol adalah $\mathrm{p}=0.000<0.05$ yang artinya terdapat perbedaan yang signifikan atau bermakna antara keputihan pada kedua kelompok. Berdasarkan hasil penelitian ini dapat disimpulkan bahwa Pemberian daun sirih merah berpengaruh dalam mengatasi keputihan patologispada remaja putri.

\section{DAFTAR PUSTAKA}

Candrasari, Anika. M, Romas. A, Hasbi. M, \& Astuti. (2012). Uji daya antimikroba ekstrak etanol daun sirih merah (piper crocatum) terhadap staphylococcus aureus, eschericia coli dan candida albicans secara in vitro, 4(1), 9-16.

Firmanila. F, Dewi. I.Y, \& Kristiani. D (2014) Pengaruh Penggunaan Air Rebusan Daun Sirih Merah Terhadap Keputihan Pada Wanita Usia Subur (Wus) Di Wilayah Kerja Puskesmas Rawat Inap Tenayan
Raya. Jurnal Ners Indonesia, Vol.6 No.1, September 2016.

Kurniawati, Riffqoi. (2013). Hubungan perilaku pencegahan keputihan dengan kejadian keputihan patologi pada remaja putri di SMA N 1 Pegandon Kabupaten Kandal. Skripsi. Stikes Ngudi Waluyo.

Kustanti. C (2016) tentang Pengaruh Pemberian Air Rebusan Daun Sirih Hijau Terhadap Kejadian Keputihan. Jurnal Keperawatan Notokusumo Volume $V$ No 1 Agustus 2017

Martin. (2010). Perbedaan efek antifungi minyak Atsiri Daun Sirih Hijau, Minyak Atsiri Daun Sirih Merah Dan ResikV Sabun Sirih Terhadap Pertumbuhan Candida Albicans Secara In Vitro. Fakultas Kedokteran Universitas Sebelas Maret Surakarta.

Nisa, Khoirun, Wahyunanto, \& Yusuf. (2014). Ekstrasi daun sirih merah (piper crocatum) dengan metode microwave assisted extraction. Jurnal Bioproses Komoditas Tropis. (MAE), 2(1), 72-78.

Nursalam. (2015). Metodologi penelitian ilmu keperawatan : pendekatanpraktis. Edisi 3. Jakarta : Salemba Medika.

Octaviyati, Namira. (2012). Hubungan pengetahuan mengenai kebersihan genitalia eksterna dengan kejadian keputihan pada mahasiswi fakultas MIPA UNS. Fakultas Kedokteran Universitas Sebelas Maret Surakarta.

Solikhah, Rizqi, Marsito, Nurlaila. (2010). Hubungan tingkat pengetahuan tentang keputihan dengan perilaku remaja putrid dalam menjaga kebersihan diri di desa Bandung kecamatan Kebumen kabupaten Kebumen Jurnal ilmiah kesehatan keperawatan., 6(2), 63-70.

Utami, Sri (2014). tentang Efektifitas Penggunaan Rebusan Daun Sirih Terhadap Penurunan Keputihan Pada Pekerja Seks Komersil Di Resosialisasi Rowo Sari Atas Mangkang. http://repository.unissula.ac.id/1611/

Werdhany, W. Indri, Marton. A, Setyorini. (2008). Sirih merah. Balai Pengkajian Teknologi Pertanian Yogyakarta. 